\title{
RIO GRANDE DO SUL: UMA PROPOSTA DE REGIONALIZAÇÃO GEOECONÔMICA
}

\section{Rio Grande do Sul: a proposal of geoeconomic regionalization}

\author{
Helena Brum Neto \\ Mestranda do Programa de Pós-Graduação em Geografia e Geociências PPGGEO/CCNE/UFSM \\ southelen@yahoo.com.br \\ Meri Lourdes Bezzi \\ Professora Associada do Depto. de Geociências/CCNE/UFSM \\ meri@oslo.ccne.ufsm.br \\ Roberto Barboza Castanho \\ Professor Adjunto da Faculdade de Ciências Integradas do Pontal/FACIP/Campus de Ituiutaba \\ robertocastanho@pontal.ufu.br
}

Artigo recebido para publicação em 28/05/2007 e aceito para publicação em 07/08/2007

RESUMO: A abordagem regional reflete a inter-relação sociedade-natureza em diferentes nuances a partir da construção do espaço geográfico. O enfoque da pesquisa foi definido em virtude dos objetivos propostos para a análise regional, uma vez que a mesma engloba os aspectos humanos $e$ as relações que mantêm entre si na produção e reprodução do espaço. Tendo como foco central a questão regional gaúcha, propôs-se regionalizar o Rio Grande do Sul, considerando os aspectos geoeconômicos. Tal proposição de estudo individualizou sete regiões geoeconômicas $e$ sub-regiões, nas quais se desenvolveram as principais atividades produtivas do Estado, baseadas, principalmente, na agropecuária. Considerando as transformações impostas pelo capital, como agente reorganizador dos padrões espaciais e responsável pela sua flexibilização frente às exigências impostas pelo processo de globalização, procurou-se classificar as regiões geoeconômicas de acordo com a sua dinâmica e em função dos novos atores econômicos que se inserem neste espaço. Pôde-se observar, então, as semelhanças e singularidades materializadas no território gaúcho pelo acúmulo de práticas voltadas à produção econômica, estritamente atreladas à questão da identidade cultural em função da expressividade do regionalismo no Estado gaúcho.

Palavras-chave: Rio Grande do Sul, Regiões Geoeconômicas, Desenvolvimento Local/Regional, Organização do Espaço, Agropecuária.

ABSTRACT: The regional approach reflects the society-nature inter-relation in different nuances going from the onstruction of the geographical space. The focus of the research was defined from the objectives proposed for the regional analysis, once the same embodies the human aspects and the relations that mantain between each other in the production and reproduction of the space. Having as central focus the southern regional matter (in Rio Grande do Sul), it was proposed the regionalization of the state, considering its geoeconomical aspects. Such proposition of 
study divided seven geoeconomic regions and sub-regions, in which the main productive activities of the state were developed, based, mainly, in farming. Considering the transformations imposed here by capital, as reorganizer agent of the spacial standards, and responsible for its flexibility, front to the requirements imposed by the globalization process, it was tried to classify the geoeconomic regions according to its dynamics and according the new economic agents that are inserted in this space. It was possible to observe that, therefore, the similarities and singularities materialized in the state territory throught the accumulation of practices turned to the economical production, strictly linked to the question of cultural identity because of the expression of regionalism in the Rio Grande do Sul state.

Keywords: Rio Grande do Sul, Geoeconomic Regions, Local/Regional Development, Spacial Organization, Farming.

\section{INTRODUÇÃO}

A região se configura, atualmente, como a materialização da complexa relação estabelecida entre sociedade e natureza. Portanto, reflete as similaridades e, ao mesmo tempo, as desigualdades impostas pelos distintos níveis de desenvolvimento socioeconômico. Parte-se do pressuposto de que o conhecimento da dinâmica regional permite conceber a região como uma sucessão de estruturas e processos que, ao se modificarem no tempo, alteram as funções das formas passadas, recriando novas formas regionais.

Os estudos relativos à questão regional permitem entender o presente, materializado pelas formas predominantes e mais significativas para um determinado recorte espacial, bem como, inferir sobre o futuro deste espaço, uma vez que o constante conflito entre o velho e o novo proporciona transformações, nas quais velhas formas se adaptam a novas funções.

Salienta-se que os processos de regionalização devem ser constantemente revisados em virtude da dinâmica evolutiva das sociedades, podendo gerar novos recortes espaciais. Pode-se dizer que, atualmente, um dos principais agentes reorganizadores do espaço é o capital, principalmente, se consideramos a visão globalizante do mundo, que impõe novos questionamentos à questão regional, fundamentalmente, no que se refere à organização do espaço produtivo, fruto da complexidade socioeconômica.

Neste sentido, a proposta da regionalização geoeconômica para o Rio Grande do Sul resultou de preocupações pertinentes à abordagem regional e à globalização que impõem constantemente mudanças, as quais se concretizam e reestruturam o espaço gaúcho.

Para tanto, os objetivos norteadores desta pesquisa buscaram: (a) fornecer uma proposta de regionalização geoeconômica para o estado gaúcho; (b) espacializar, via geração de mapas e geotecnologias, a proposta de regionalização geoeconômica do Rio Grande do Sul; (c) analisar o espaço produtivo das regiões geoeconômicas quanto aos seus principais aspectos socioespaciais e (d) divulgar junto ao Governo Gaúcho e nas unidades territoriais a proposta de regionalização realizada para que as sugestões elaboradas sejam consideradas e utilizadas para atingir o desenvolvimento local e/ou regional.

Dessa forma, inicialmente, o Rio Grande do Sul foi recortado em sete regiões geoeconômicas, em função da agropecuária, principal atividade econômica das unidades territoriais do Estado. Posteriormente, estabeleceram-se três regiões de acordo com a adaptação da proposta de regionalização de Bacelar (1999), a qual individualizou: (a) regiões 
dinâmicas e competitivas no Rio Grande do Sul; (b) regiões em processo de reorganização espacial no estado gaúcho e (c) regiões com potencial pouco utilizado no Estado.

Inicialmente, fez-se o resgate referente às matrizes teórico-metodológicas que nortearam esta pesquisa, centrada no conceito-chave de região, para que se pudesse entender a evolução deste conceito e sua atual concepção. Paralelamente, utilizou-se de conceitos chaves como regionalização, desenvolvimento local/regional e identidade cultural para explicar a dinâmica socioespacial gaúcha em virtude da expressividade do regionalismo no Rio Grande do Sul, que tem sua identidade também vinculada aos aspectos econômicos em algumas porções do seu território.

A partir do direcionamento proporcionado pela conceitualização da questão regional e do entendimento de região como uma resposta local aos processos capitalistas (Gilbert, 1988), pode-se definir e delimitar as regiões do Rio Grande do Sul seguindo critérios geoeconômicos.

Desta forma, entende-se que a região, na atualidade, passa por dinâmicas impostas no território, via capital, que organiza, desorganiza e reorganiza o território. As regiões geoeconômicas propostas, foram então delineadas, entendendo a dinâmica que o conceito de região possui, o que levou a recortar o território gaúcho em sete regiões geoeconômicas. Para esta finalidade foi necessário entender também os processos naturais, históricos, culturais e, principalmente, os econômicos que forjam constantemente a presença novos arranjos espaciais responsáveis pela introdução de novas cadeias produtivas no estado gaúcho.

Com esse suporte teórico, pode-se estabelecer conceitos, traçar parâmetros e indicadores de investigação, além de estruturar e propor a regionalização geoeconômica para o Rio Grande do Sul.

Outra etapa importante para o desenvolvimento da pesquisa esteve atrelada ao resgate teórico, enfatizando os aspectos histórico-culturais do território gaúcho. Este permitiu entender que a dinâmica territorial está fortemente assentada no processo de ocupação e colonização do Estado, o qual é responsável pela organização de distintos arranjos geoeconômicos que refletem a formação étnico-cultural, determinando as principais atividades econômicas que foram essenciais para o recorte das regiões geoeconômicas.

No que se refere aos aspectos físicos, estes foram determinantes, uma vez que as potencialidades físico/naturais permitem, de formas diferenciadas, a ação do homem e da tecnologia no território. Para subsidiar as características naturais, elaborou-se o terceiro capítulo, que resgata os principais compartimentos geológicos-geomorfológicos, além do clima e solo. Estes aspectos são fundamentais, considerando-se que são elementos essenciais para as atividades econômicas, servindo como fatores limitantes para a agricultura e à pecuária e, conseqüentemente, possibilitando de maneira distinta sua utilização.

Neste sentido, para regionalizar o território gaúcho, teve-se como diretrizes básicas atrelar os aspectos culturais que, sem dúvida, são responsáveis pela estrutura econômica das regiões, aos econômicos, recortando o Estado gaúcho em sete regiões geoeconômicas.

Paralelamente, considerou-se, também, para realizar a regionalização, a heterogeneidade espacial, ou seja, a presença desigual do capital no setor primário. Pode-se perceber que o Estado gaúcho estrutura sua economia evidenciando regiões dinâmicas e competitivas, ao lado de outras, em processo de reestruturação, ou então, estagnadas e/ou com potencial pouco utilizado. Esta diversidade do setor produtivo é resultante das diferentes formas de ocupação territorial, através das diversas correntes migratórias ocorridas no Estado gaúcho, as quais impuseram organizações espaciais desiguais, em tempos distintos.

Neste contexto, as sete regiões geoeconômicas estabelecidas tiveram origem, considerandose, entre outros fatores, a dicotomia da sua estrutura 
fundiária, ou seja, a pequena e a grande propriedade; áreas com potencial industrial representativo; áreas com disponibilidade e outras com falta de mão-deobra; áreas com potencial turístico; áreas privilegiadas pela presença da malha viária, áreas com escoamento da produção e áreas com presença de novas cadeias produtivas como a da fruticultura e do florestamento que buscam dinamizar, principalmente a Metade Sul do Rio Grande do Sul.

O laboratório de estudo desta pesquisa constitui-se nos 496 municípios que compõem atualmente o território gaúcho. Para cada unidade territorial foram coletadas informações referentes às variáveis que se faziam presentes na mesma, sendo este o critério determinante para subsidiar o agrupamento dos municípios e posterior formação da região geoeconômica que o mesmo viria compor. É importante salientar que, na escolha das variáveis que caracterizaram o município, o critério estabelecido foi o de maior área plantada, sendo este, portanto, o elemento que levou a individualizar os recortes espaciais.

Embasado na fundamentação teórica, selecionou-se os critérios que nortearam a regionalização geoeconômica proposta, bem como as variáveis e os atributos que foram selecionados para esta regionalização. As variáveis utilizadas foram a área plantada dos produtos selecionados, a produtividade e o rendimento médio da produção. Além disso, se considerou, para análise, o PIB, a inserção do município na economia do Estado, entre outros fatores.

Para esta fase, primeiramente, realizou-se a coleta de dados no site do IBGE (www.ibge.gov.br/ @cidades), referente às variáveis selecionadas. Na agricultura, coletaram-se dados sobre área plantada (ha), quantidade produzida (tons.) e rendimento médio (kg/ha). Há que se destacar que as variáveis referentes à agricultura se subdividiram em lavouras temporárias e lavouras permanentes. Nas lavouras temporárias, as culturas mais significativas do Estado gaúcho foram: arroz, soja, trigo, milho, fumo, feijão, batata-inglesa e mandioca. Com relação à lavoura permanente, as variáveis selecionadas foram: uva, maçã, banana, pêssego, laranja, tangerina. Já, na pecuária, as variáveis de maior destaque foram: bovinos, suínos e aves (incluindo galos, galinhas e pintos), considerando o número de cabeças por município.

Além disso, procurou-se demonstrar, em cada região geoeconômica, as áreas com maiores e menores rendimentos médios para cada produto dominante. Isto permitiu verificar que as unidades territoriais mais produtivas são aquelas que aliam as potencialidades físico-naturais aos investimentos tecnológicos.

Salienta-se que as informações referentes ao florestamento basearam-se no eucalipto, pinus e acácia e foram coletadas em sites específicos sobre a temática, reportagens em jornais de circulação local e estadual, além de informações junto as prefeituras dos municípios em que esta cadeia produtiva está se inserindo.

Definidas as variáveis, delineou-se a parte prática da pesquisa. A investigação baseou-se em fontes primárias realizadas através de trabalho de campo (entrevistas) junto aos municípios, aferindo as variáveis referentes à temática em estudo. Paralelamente, utilizou-se de fontes secundárias através de dados estatísticos fornecidos pela Fundação de Economia e Estatística (FEE); Fundação Instituto Brasileiro de Geografia e Estatística (IBGE) referente ao período de 2003/2004/2005; Secretaria de Planejamento dos Municípios; Secretaria de Agricultura dos Municípios, Conselhos Regionais de Desenvolvimento (COREDES); Assembléia Legislativa do Rio Grande do Sul e demais órgãos estaduais e municipais.

Ressalta-se que os dados coletados foram tabulados em planilhas previamente elaboradas no software Word, possibilitando, posteriormente, sua inserção no software ArcView GIS 3.2a. Este possibilitou agregar os dados que foram a base para as etapas de análise, interpretação e espacialização dos mesmos. Paralelamente, foram sendo gerados os recortes espaciais responsáveis pela formação das 
sete regiões geoeconômicas.

Para se recortar o espaço gaúcho em sete regiões geoeconômicas, obedeceu-se as seguintes etapas:

1. Coleta de dados no site do IBGE, referente à produção primária do Rio Grande do Sul, como dados de área plantada, quantidade produzida e rendimento. Selecionaram-se, na agricultura, as culturas mais significativas e, na pecuária (bovina, ovina ou aves), as mais significativas existentes nas unidades territoriais gaúchas;

2. Delimitação das regiões geoeconômicas que foram geradas considerando-se as culturas mais significativas em área plantada e, na pecuária, o número de cabeças por município. Estes critérios foram base para se proceder ao recorte do espaço gaúcho;

3. Recorte Espacial das sete regiões geoeconômicas do Rio Grande do Sul:

(a) Região Geoeconômica 1 - Para se gerar esta região, considerou-se a produção que predominou em quase todos os municípios, ou seja, o arroz e a pecuária bovina, sendo, portanto, estes os produtos que constituíram a matriz tradicional dessa região. No entanto, a área plantada e número de cabeças por município apresentaram-se bastante variáveis. Para solucionar esta problemática, adotouse como critério que os municípios que comporiam a região geoeconômica seriam aqueles com expressão mais significativa naquela cultura e pecuária bovina. Desta forma, predominou, nesta região, a matriz tradicional que, conseqüentemente, foram os produtos responsáveis pela formação desta região. No entanto, algumas unidades territoriais, além de apresentarem arroz e pecuária, coexistem com outras culturas. Tal situação nos conduziu a criar três sub-regiões: subregião $A$, com predomínio da pecuária bovina, arroz e soja; sub-região $B$, com predomínio da pecuária bovina, do arroz e do fumo e a sub-região $C$, com predomínio da pecuária bovina, do arroz e do milho.
As três sub-regiões são também entendidas como áreas de transição, considerando que as mesmas apesar de terem suas bases econômicas ligadas aos produtos tradicionais que caracterizam historicamente a região, apresentam a inserção de novos produtos, os quais se identificam como arranjos econômicos que são dinamizados por cadeias produtivas recentes que procuram inserir perspectivas à região geoeconômica como um todo. Como exemplo, tem-se a sub-região A, na qual a soja coexiste com a matriz tradicional (pecuária e arroz) e demonstra a transição para a região geoeconômica 7 , onde o principal produto primário é constituído pela soja, demonstrando que no espaço não há rupturas bruscas.

(b) Região Geoeconômica 2 - Foi gerada pelo predomínio das culturas do fumo e do milho. Salienta-se que esta região não apresentou contigüidade espacial, ou seja, originou dois recortes espaciais distintos, demonstrando que ocorre uma dinâmica espacial onde as culturas são desenvolvidas em alguns municípios enquanto que, em outros, as mesmas não se fazem presentes. A descontinuidade espacial, também entendida como transição, demonstra a presença de outros produtos distintos da matriz tradicional da região geoeconômica 2, como o arroz e a pecuária, que passam a coexistir junto ao fumo e ao milho, constituindo-se, portanto, numa área de transição entre os dois recortes espaciais que constituem esta região.

(c) Região Geoeconômica 3 - Foi criada considerando-se o predomínio das culturas do milho, seguida pela cultura da mandioca e da batata inglesa, além da fruticultura e, na pecuária, pela avicultura.

Esta região geoeconômica foi recortada levando-se em conta a cultura predominante, o milho, que se faz presente de forma significativa em grande parte das unidades territoriais. Em segundo lugar, tem destaque a cultura da mandioca, seguida da batata-inglesa e das frutas (laranja, tangerina e pêssego). Ressalta-se que esta região geoeconômica é constituída por um número expressivo de municípios que fazem parte da Região Metropolitana de 
Porto Alegre, na qual se localiza um dos principais pólos industriais gaúchos. Portanto, a expressividade do setor primário desta região é menor à medida que se aproxima da Região Metropolitana, pois a economia dos municípios que a circunda está alicerçada ao setor secundário (químico, metal-mecânico, moveleiro, coureiro-calçadista, entre outros). No entanto, como esta proposta de regionalização teve como critério o setor primário, foram considerados os principais produtos da agropecuária desta região. Desta forma, fica evidente que o setor secundário se sobressai ao primário, o que explica a baixa produção agrícola dos municípios desta região. Entretanto, à medida que se distancia da Região Metropolitana de Porto Alegre, as unidades territoriais passam a ter maior expressão através do setor primário, constituindo-se numa área de transição para as regiões circunvizinhas (regiões geoeconômicas 2, 4, 5 e 6).

(d) Região Geoeconômica 4 - Foi gerada pelo predomínio da cadeia produtiva da uva e, na pecuária, pela presença da avicultura. Em relação as outras regiões geoeconômicas, a 4 apresentou uma singularidade, caracterizando-se por ser uma das regiões que se individualizou espacialmente através da lavoura permanente, baseada na uva. Tal fato justifica-se por ser uma cultura característica da colonização italiana que se apropriou economicamente deste espaço via processo colonizador, que tinha estas áreas como prioritárias para as correntes migratórias européias. Paralelamente à agricultura, a atividade pecuária também se faz presente através das aves, criação típica das áreas coloniais do Estado gaúcho.

(e) Região Geoeconômica 5 - Foi estruturada considerando-se o predomínio da cultura da maçã. Esta região foi individualizada como um recorte espacial resultante da lavoura permanente. É importante salientar que a existência de outras culturas de menor expressividade, como é o caso da batatainglesa, se fazem presentes, principalmente, nos municípios de São Francisco de Paula, Cambará do Sul, entre outros, os quais fazem transição com a região geoeconômica 3, na qual esta cultura apresentase como produto característico. A presença da soja, principalmente nos municípios localizados a noroeste desta região constitui-se em outra transição, uma vez que a região 7 foi individualizada por esta cultura.

Outro elemento que caracterizou este recorte espacial e, portanto, o difere dos demais é a presença do florestamento, que é uma atividade importante, pois agrega valor na base econômica dos diversos municípios que compõem esta região geoeconômica.

A pecuária tem expressão significativa nesta região através dos bovinos de corte. Ressalta-se que esta região caracteriza-se por municípios de maiores dimensões territoriais resultantes da presença da pecuária, atividade característica de seu processo histórico de formação econômico-territorial.

(f) Região Geoeconômica 6 - Foi gerada pelo predomínio da cultura da banana, uma vez que esta cultura individualizou-se como produto-chave para originar esta região geoeconômica. Além da banana, também é expressiva a cultura do abacaxi e do palmito. O turismo evidencia-se como uma atividade predominante na maior parte dos municípios que compõem esta região, uma vez que se caracterizam como municípios litorâneos, tendo no período de veraneio sua economia voltada para esta atividade.

Salienta-se que a atividade turística agrega valores para a economia destes municípios principalmente nos períodos de férias (dezembro, janeiro, fevereiro e, também em julho), mas a base econômica da região está alicerçada nas culturas temporárias da banana, do abacaxi e do palmito, que se constituem na base do setor primário desta região.

(g) Região Geoeconômica 7 - Foi estruturada pelo predomínio das culturas de soja, trigo e milho e, na pecuária, pelos bovinos e aves. A cultura da soja foi o principal fator para individualizar esta região geoeconômica, pois predomina em área plantada na maioria dos municípios que a compõe. Também se apresentam como culturas expressivas o trigo e o milho. O trigo, constituindo junto com a soja o binômio trigo-soja é responsável pelo início do processo de modernização no Rio Grande do Sul, 
a partir da década de 70. Por outro lado, o milho, bastante significativo nesta área e em outras do Estado gaúcho, destaca-se por ser uma alternativa à cultura da soja, proporcionando até três safras anuais.

É uma cultura mais resistente que a soja, suportando as estiagens que ocorreram no Estado na última década. Além disso, é uma cultura básica para retroalimentar a cadeia produtiva da avicultura e da suinocultura, que tem se expandido de forma gradativa na porção centro-norte do Rio Grande do Sul.

É importante ressaltar que a região geoeconômica 7 foi recortada em duas sub-regiões através da pecuária bovina e das aves. A sub-região $7 \mathrm{~A}$, resultou em uma descontigüidade espacial através da pecuária bovina, e constitui-se numa área de transição da região geoeconômica 1 (pecuária, arroz, soja), e da região geoeconômica 5 (maçã e pecuária). Esta sub-região resgata o processo histórico de ocupação territorial destas regiões e que teve na pecuária a sua base econômica, a qual foi, no decorrer do tempo, via introdução do capital, atrelada à agricultura, a responsável pela presença das culturas temporárias da soja e do trigo.

A sub-região 7 B foi individualizada pela presença da avicultura, atividade econômica típica de áreas coloniais, que tiveram seu processo de colonização originadas do desmembramento das velhas colônias gaúchas. Constituíam-se em áreas, na sua maior parte, devolutas, uma vez que por limitações físico-naturais dificultavam o desenvolvimento de atividades agrícolas. Assim, estas áreas foram disponibilizadas pelas políticas governamentais da época às correntes migratórias européias.

É importante ressaltar também que esta subregião apresenta uma diversidade produtiva, na qual estão inseridos a fruticultura e o feijão, além da matriz tradicional, dada pela soja, trigo e milho.

4. Com base nos critérios adotados para estabelecer este recorte espacial concretizaram-se as sete regiões geoeconômicas do Estado gaúcho que foram espacializadas, representando a regionalização final, composta de 7 regiões geoeconômicas e suas sub-regiões.

5. Posteriormente, as sete regiões geoeconômicas foram reorganizadas, adaptando-se à regionalização de Bacelar (1999), em três regiões: regiões dinâmicas e competitivas; regiões em processo de reorganização espacial e regiões com pouco potencial utilizado.

Quanto a etapa de elaboração dos mapas, utilizou-se o software ArcView GIS 3.2a, desde a constituição do banco de dados até a elaboração dos layouts finais dos mesmos.

Assim, a primeira etapa consistiu-se na elaboração do banco de dados, contendo as informações referentes aos municípios gaúchos no que tange à produção agropecuária.

O banco de dados estruturado serviu de base para estabelecer os cruzamentos entre as variáveis pré-selecionadas, gerando os mapas de acordo com as variáveis que melhor regionalizaram os distintos espaços econômicos gaúchos.

Estruturado o banco de dados no software Arcview, iniciou-se a organização dos mapas. Nesta etapa, primou-se pela categorização dos intervalos, tais como as cores das classes, os tipos de símbolos a serem usados, entre outros, permitindo, assim, a visualização dos mapas já espacializados de acordo com os dados inerentes a cada município.

Nesse sentido, de acordo com a variável a ser espacializada, estipulou-se os intervalos de classes desejados, sendo alguns casos de 5 e outros em 7 classes, primando pela melhor representatividade da variável que estava sendo analisada.

A análise e interpretação dos mapas, compostos pelas diferentes variáveis, realizou-se através de revisões bibliográficas e análise geográfica da espacialização dos mesmos, bem como a reflexão acerca do conhecimento empírico da realidade do Estado Gaúcho. 
Posteriormente, fez-se o cruzamento das variáveis em estudo no software ArcView e, concomitantemente, analisou-se as mesmas com o intuito de identificar a espacialização das que melhor apresentaram uma regionalização econômica e espacial no Estado.

A partir deste cruzamento, passou-se a delimitar as regiões de acordo com dois critérios: (a) para o primeiro critério de delimitação das regiões estabeleceu-se utilizar para todas variáveis da agricultura a área plantada e, para a pecuária o número de cabeças; (b) O segundo critério constituiu-se no cruzamento de vários mapas, contendo variáveis distintas, a fim de identificar a contigüidade da produção agropecuária para posterior classificação das variáveis de maior relevância em cada região delimitada.

Considerando-se a regionalização proposta, realizou-se a análise e interpretação das regiões geoeconômicas geradas. Cada região foi interpretada e analisada através de uma visão sistêmica, que procurou inter-relacionar os aspectos físico-naturais, socioeconômicos, políticos e culturais. Esta interação subsidiou a releitura do espaço gaúcho, demonstrando que a dinâmica territorial tem no capital seu principal agente econômico transformador.

Neste contexto, o capital permite que as regiões se organizem e se reorganizem mediante sua inserção, que ocorre de forma desigual e de acordo com as solicitações do mercado nas diversas escalas: local, regional, nacional e internacional e, que, conseqüentemente, são responsáveis pelos arranjos econômicos que permitem a inserção de novas cadeias produtivas. Estas, por sua vez, não devem ser entendidas como fixas, uma vez que o espaço tem uma característica iminente que é a sua dinâmica. A exemplo disso, tem-se a cadeia do florestamento inserida na região geoeconômica 1 , desafiando, de certa forma, a presença secular da pecuária e do arroz.

Assim, estruturada essa regionalização, baseada em sete regiões geoeconômicas, acredita-se que a mesma possa auxiliar a tomada de decisões consistentes para prever ações voltadas para o desenvolvimento do Rio Grande do Sul e, desta forma, integrá-lo no espaço nacional, auxiliando a inserção competitiva do Brasil no mundo em globalização.

É importante ressaltar que os problemas detectados nas regiões geoeconômicas propostas destacam as desigualdades produtivas do setor primário gaúcho demonstrando as áreas com dinâmica e competitividade, as regiões em reestruturação espacial e as com potencial pouco utilizado.

\section{AS REGIÕES GEOECONÔMICAS DO RIO GRANDE DO SUL}

A configuração de uma região resulta em sua identidade. Esta confere a mesma personalidade e unidade e, também, influencia na sua organização espacial, proporcionando-lhe funcionalidades distintas. Portanto, a região é resultante dos laços que a sociedade mantém com seu espaço. Assim, pode-se considerar seu caráter mutável, pois o espaço é dinâmico e sua delimitação não pode ser rígida. As transformações socioeconômicas que acompanham a evolução da sociedade refletem-se diretamente sobre sua base espacial, organizando-a e reorganizando-a, fazendo com que se configurem regiões com diversas finalidades, de acordo com os propósitos estabelecidos para realizar determinado recorte espacial.

Neste sentido, esta proposta de regionalização recortou o Rio Grande do Sul em sete regiões geoeconômicas, baseadas na atividade agropecuária, uma vez que essa atividade constituiu-se, desde os primórdios do seu processo de ocupação e colonização, no principal agente organizador do espaço riograndense. (Figuras 1 e 2).

Desse modo, a região geoeconômica 1 individualizou-se em função da pecuária bovina de corte e das lavouras de arroz, que compõem o que se denominou de matriz produtiva tradicional. Constituise na maior região em extensão territorial e na segunda 
em maior número de unidades territoriais (municípios). Sua origem está atrelada ao processo de ocupação e povoamento do Rio Grande do Sul, baseada na doação de sesmarias, as quais originaram os latifúndios pastoris do Estado. (Figuras 1 e 2).

A estrutura fundiária deste recorte espacial permanece, na atualidade, fundamentada em grandes propriedades, como resquícios do passado estancieiro e charqueador. Entretanto, é significativa a presença das lavouras comerciais, representadas principalmente pelas culturas de arroz e da soja. Salienta-se também que, na atualidade, esta região é palco de manifestações exercidas pelos movimentos sociais de luta pela terra (MST), que reivindicam uma distribuição mais eqüitativa da terra e lutam, inclusive, pela reforma agrária.
A economia da região geoeconômica 1 , embora baseada na matriz tradicional (pecuária de corte e arroz), teve a inserção de outras cadeias produtivas como a da soja, a do fumo e do milho. Estas culturas permitiram individualizar, neste recorte espacial, três sub-regiões geoeconômicas denominadas, respectivamente de: 1A, 1B e 1C. Tal situação demonstra sua dinâmica que busca aliar a tradição pecuarista às novas demandas do mercado, procurando capitalizar sua produção e, ao mesmo tempo, evitar a sua estagnação. (Figura 1).

Destaca-se também que esta região manteve sua forma de produzir no decorrer do tempo. Entretanto, alterou sua função, visando a justificar a manutenção diante das exigências impostas pela dinâmica do capital, que recorta distintamente o território gaúcho.

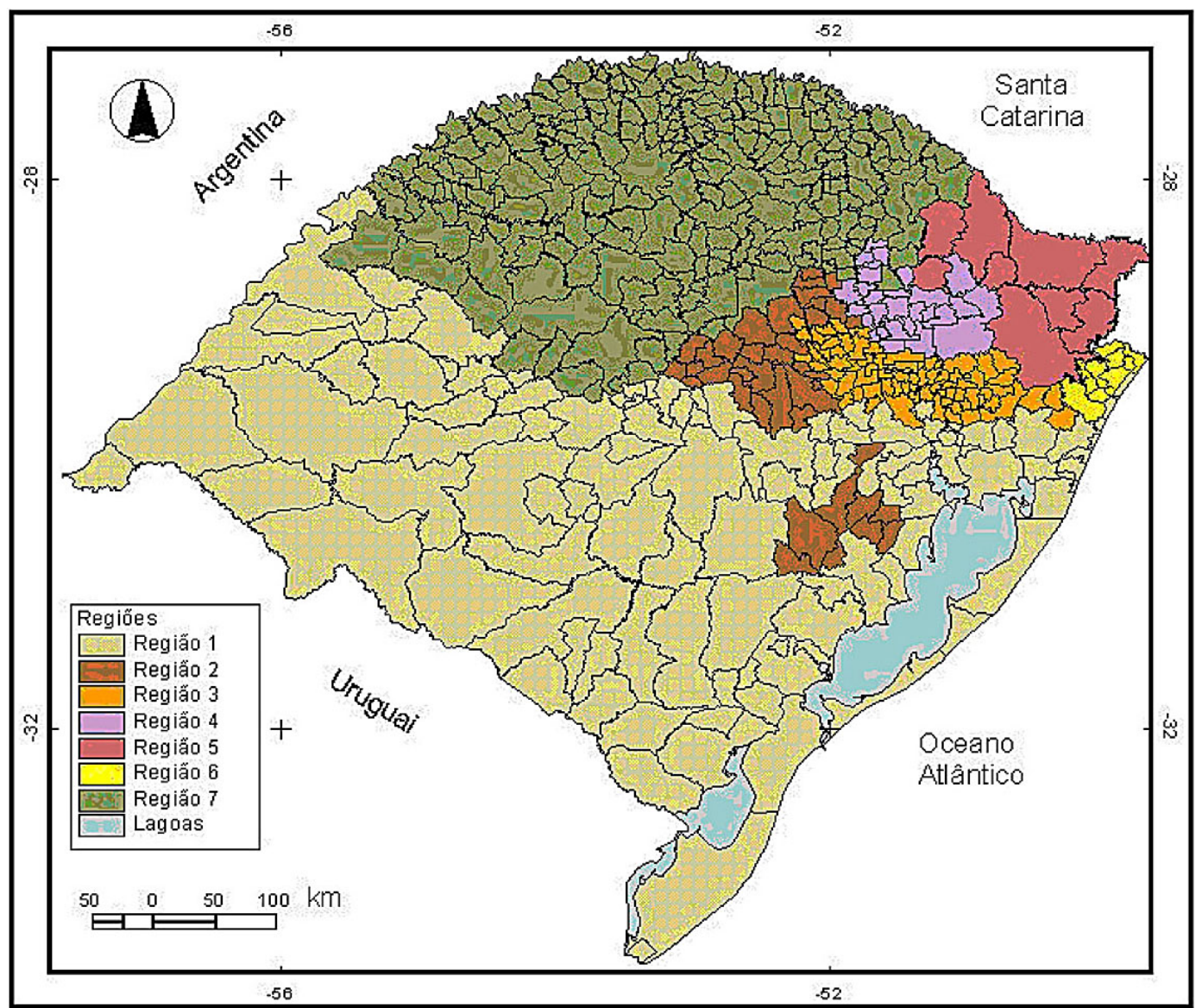

Figura 1. Regiões Geoeconômicas do RS.

Fonte: Elaboração a partir do software ArcView 3.2a.

Org.: Equipe técnica - NERA/2005 
A sub-região $1 A$ demonstra a coexistência da matriz tradicional (pecuária bovina e arroz) com a cultura da soja. Esta tem se expandido através de diversas lavouras no Estado e, constitui-se como uma área de transição entre as regiões geoeconômicas $1 \mathrm{e}$ 7. Tal fato demonstra que no espaço não há rupturas bruscas e que as transformações espaciais ocorrem mediatizadas pela potencialidade físico-natural aliada ao capital e à tecnologia que são assimiladas de formas distintas nesse recorte espacial.

No que diz respeito a sub-região $1 B$, esta demonstra a coexistência da matriz tradicional (pecuária bovina e arroz) com o fumo. Situa-se no centro-norte da região geoeconômica 1 , entre os dois recortes espaciais que individualizaram a região geoeconômica 2. Compõe-se de municípios com for- te influência do pólo fumageiro de Santa Cruz do Sul, mas que não abandonaram as atividades ligadas à produção de arroz e da pecuária bovina. (Figura 2).

A sub-região $1 C$, além da matriz produtiva tradicional (pecuária bovina e arroz), tem como terceiro produto o milho. Localiza-se na porção centro-leste da região geoeconômica 1 , caracterizada por significativa área plantada deste produto. (Figura 2).

Além das sub-regiões 1A, 1B e 1C, a região geoeconômica 1 manteve porções de seu espaço vinculados somente à matriz tradicional (pecuária de corte e arroz). Esses espaços encontram-se dispersos em algumas áreas da região geoeconômica 1, nas quais não houve a inserção de novas cadeias produtivas econômicas visando dinamizá-la.

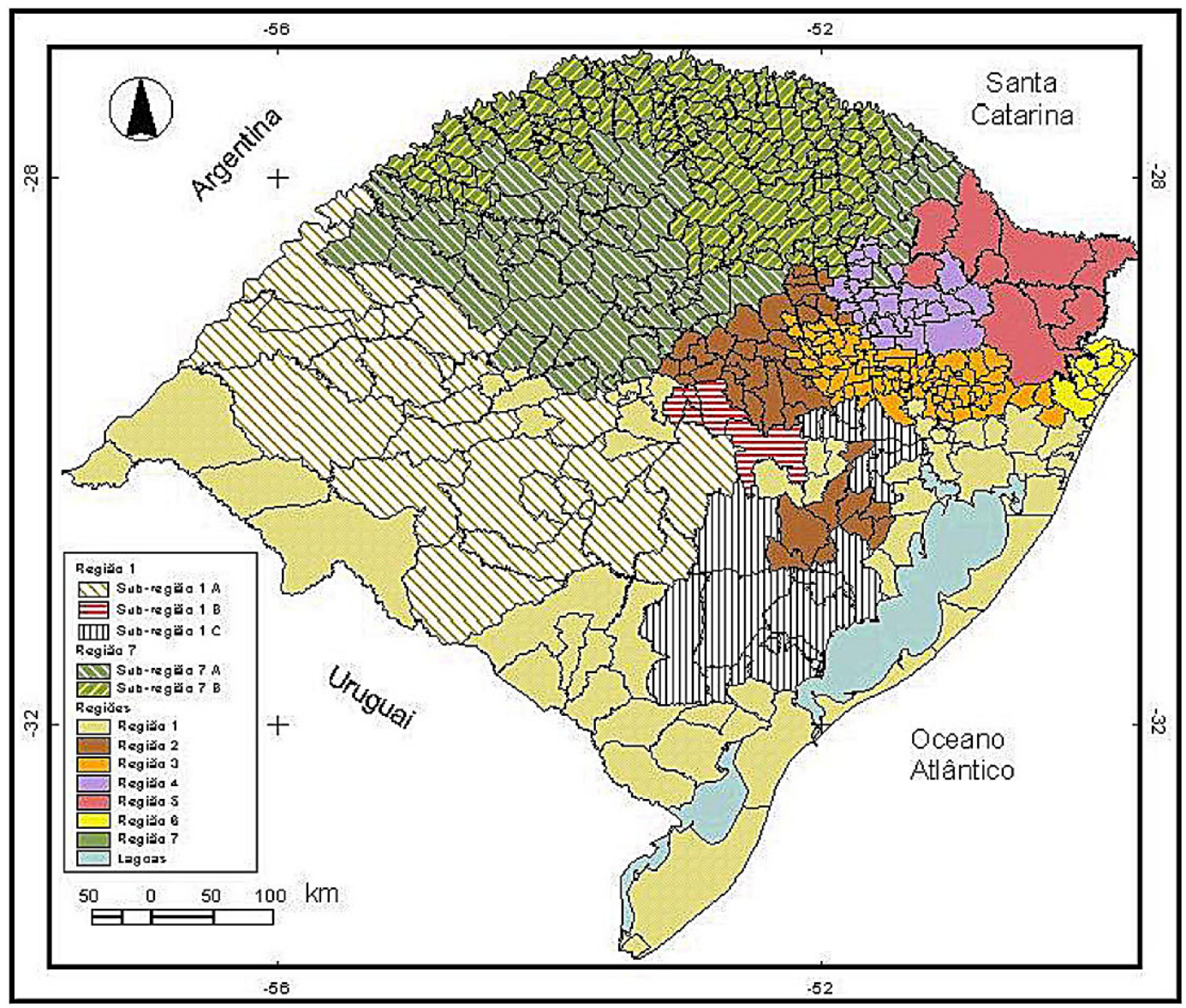

Figura 2. Regiões e sub-regiões Geoeconômicas do RS.

Fonte: Elaboração a partir do software ArcView 3.2a.

Org.: Equipe técnica - NERA/2005 
Em contrapartida, a porção leste da região geoeconômica 1, que abrange o litoral rio-grandense também compõe a matriz tradicional. No entanto, paralelamente a essas atividades, temporariamente desenvolve-se a atividade turística, bastante significativa para os municípios desta região geoeconômica. Salienta-se que a presença da agropecuária é expressiva, sendo uma atividade responsável pela base de sua economia, cabendo ao turismo uma atividade complementar, desenvolvida no período de veraneio.

A presença de novos arranjos econômicos, representados pelas cadeias produtivas da fruticultura e do florestamento, estão buscando dinamizar este recorte espacial. A fruticultura surge como cadeia produtiva em expansão, com destaque para os cítricos, a uva, o pêssego e o figo. A presença desta atividade econômica foi incentivada por políticas públicas de financiamento, fomentadas pelo governo estadual, através do Programa Estadual de Incentivo à Fruticultura (PROFRUTA). Ressalta-se que esta iniciativa tem apoio dos pequenos produtores rurais que apostam na fruticultura como uma alternativa para dinamizar a Metade Sul do Estado.

Desse modo, novos pólos produtores da cadeia produtiva da fruticultura têm surgido no Estado, localizando-se, principalmente, no extremo oeste e no centro-sul da região geoeconômica 1, representados pelos cultivos da uva e dos cítricos, principalmente a laranja e tangerina.

No que se refere ao florestamento, os investimentos têm se concentrado na porção oeste desta região geoeconômica, principalmente nos municípios que compõem a sub-região 1A. Esta atividade econômica caracteriza-se pelo investimento de grandes grupos ligados à produção de celulose, como o Grupo Votorantin-Celulose e Papel (nacional), a Aracruz Celulose (nacional), e a Stora-Enso (suecofinlandeza), que alicerçam sua produção no plantio de pinus e eucalipto em grandes áreas. Distintamente do que ocorre com suas culturas agrícolas (arroz, soja, fumo e milho) que se inseriram neste recorte espacial, através do arrendamento das terras da pe- cuária tradicional, o florestamento está sendo implantado em áreas próprias, adquiridas via desmembramento das grandes propriedades. Há o rompimento das práticas tradicionais de exploração deste recorte espacial, ou seja, as atividades pecuaristas e lavoureiras cedem espaço para a posterior produção de madeira, via inserção do capital.

Nesse contexto, individualizou-se a região geoeconômica 1 , marcada pela matriz produtiva da pecuária de corte e do arroz, associada às lavouras de soja, fumo e milho, as quais individualizaram três sub-regiões geoeconômicas, juntamente com outras atividades que vieram agregar valor a este espaço produtivo, como a fruticultura e o florestamento. Esta situação atesta que uma região não pode ter seus limites fixos, uma vez que, na atualidade, a descontinuidade espacial também permite individualizar regiões e/ou sub-regiões, pois as ações humanas tornam o espaço dinâmico, fazendo com que haja mudanças ao longo do tempo, mesmo em uma base espacial com características semelhantes. Tal fato reflete a dinâmica regional.

O segundo recorte espacial estabelecido para o Rio Grande do Sul constituiu a região geoeconômica 2, que foi individualizada pelas culturas do fumo e do milho. Possui uma peculiaridade em relação às demais, ou seja, caracterizou-se pela delimitação de duas áreas não contíguas no território gaúcho, demonstrando a dinâmica que, na atualidade, assumem a questão regional em decorrência da assimilação distinta do capital e da técnica em determinadas áreas. Portanto, cada vez mais, o espaço caracteriza-se por uma heterogeneidade que o distingue dos demais, ou seja, uma região geoeconômica de outra. Assim, estabeleceram-se dois recortes espaciais, um ao norte e o outro ao sul desta região geoeconômica.

A característica essencial da região geoeconômica 2 está assentada na produção fumageira, principal geradora de renda e tributos aos municípios que a compõe, uma vez que a mesma se constitui em um produto altamente rentável. Esta produção desenvolve-se em pequenas propriedades, com mão- 
de-obra familiar, em áreas de colonização alemã e italiana. Salienta-se que esta cultura assumiu caráter empresarial à medida que a indústria fumageira passou a organizar a produção, via pacote tecnológico, que fornece insumos e assistência técnica, além da garantia de compra da produção. A maior concentração da produção situa-se no entorno das indústrias de beneficiamento, tendo como pólo produtivo Santa Cruz do Sul.

O milho surge como segundo produto em área plantada nesta região geoeconômica, coexistindo com o fumo. Constitui-se em um produto característico das áreas de colonização européia no Rio Grande do Sul desde os primórdios de sua ocupação. Atualmente, o milho se faz presente, principalmente nas áreas mais declivosas desta região geoeconômica, juntamente com o fumo. É importante destacar, também, que a cultura do milho, tem tido, na última década, uma expansão significativa em área plantada em todo o estado gaúcho. Esta realidade é conseqüência do melhoramento genético e da expansão da avicultura na porção norte do Estado gaúcho.

Nesse sentido, a região geoeconômica 2 caracteriza-se por ter uma produção altamente rentável, via fumicultura, consorciada com outros produtos agrícolas de caráter secundário, como o milho, a avicultura e a suinocultura.

A região geoeconômica 3 tem sua base econômica assentada na cultura do milho e, na pecuária, pelas aves e suínos. No entanto, estas atividades coexistem em grande parte da região com as lavouras de mandioca, batata (em menor proporção) e fruticultura. Tal situação deve-se ao fato desta região abranger, principalmente, as áreas iniciais de colonização do Estado, caracterizadas pela diversificação da produção agropecuária, que, inicialmente, tinha caráter de subsistência. Seguindo a orientação das demais regiões coloniais, a estrutura fundiária está baseada na pequena propriedade, com mão-de-obra familiar, uma vez que os imigrantes europeus, principalmente os alemães e os italianos, receberam pequenos lotes de terra para cultivar.
No que se refere à pecuária, destacam-se os rebanhos suínos, bovinos (leite), e as aves. A atividade pecuarista desenvolveu-se na região geoeconômica 3 , caracterizando-se por se adaptar às pequenas áreas, sendo mais concentradas, em virtude da pequena extensão das terras voltadas para a agricultura familiar. Portanto, este espaço produtivo difere do espaço que configurou a região geoeconômica 1 , constituindo-se em moldes produtivos distintos, baseados em origens históricas, atividades econômicas e estruturas fundiárias peculiares, estabelecendo um contraponto na organização socioeconômica do Rio Grande do Sul.

Cabe ressaltar que a porção sul da região geoeconômica 3 abrange alguns municípios que compõem a Região Metropolitana de Porto Alegre, que tem a sua economia assentada no setor secundário (indústrias têxtil, moveleira, siderúrgica, metal-mecânica, calçadista, componentes elétricos e química), e terciário, via prestação de serviço. Enfatiza-se que, em geral, estes municípios têm sua produção primária menos significativa se comparados aos demais setores produtivos desse recorte espacial.

Destaca-se, também, que a atividade turística é desenvolvida plenamente na Serra Gaúcha que se beneficia da paisagem natural, composta por vales e montanhas, aliada ao fator sócio-cultural que a transformou, ou seja, descendentes de alemães e italianos, imprimiram seus traços característicos ao meio, conferindo-lhe uma identidade cultural peculiar. Esta atividade econômica, o turismo, proporciona serviços diversificados aos turistas, além de servir como fonte de emprego para a população local. Desse modo, a região geoeconômica 3 individualizou-se através da agropecuária colonial e da indústria e serviços em geral, configurando uma particularidade regional significativa no que tange ao seu espaço produtivo.

A região geoeconômica 4 caracterizada como área de imigração tipicamente italiana, individualizou-se, tendo como produto principal a uva, constituindo-se no pólo vitivinicultor do Rio Grande do Sul. As videiras se constituem em uma paisagem peculiar nessa porção do espaço gaúcho, pois cobrem 
Rio Grande do Sul: uma proposta de regionalização geoeconômica Helena Brum Neto, Meri Lourdes Bezzi, Roberto Barboza Castanho

desde as áreas mais declivosas até os vales intermontanos da região geoeconômica 4. Os parreirais formam uma paisagem típica na qual estão localizadas as vinícolas que fazem parte de uma rota turística, denominada Rota do Vinho.

Além da produção primária, outras atividades se concretizam e contribuem para a sua dinâmica socioeconômica, como o turismo e a indústria. Salienta-se que os aspectos físico-naturais, formados pelo conjunto de vales e montanhas, aliados aos aspectos históricos da colonização, preservam os traços culturais das etnias que vieram compor o Rio Grande do Sul. Destacam-se, principalmente, os códigos culturais da imigração italiana, formando uma paisagem singular, bastante requisitada pelos turistas. Além como a relevância do parque industrial, segunda maior concentração do Estado, formado em função das cadeias produtivas da uva e do turismo. Paralelamente, instalaram-se, nessa região geoeconômica, as indústrias têxteis, (que suprem as "famosas malharias da Serra gaúcha”), de calçados, de bebidas (vinícolas) e moveleiras, além das indústrias metal-mecânicas.

A diversificação da produção confere a este recorte espacial inúmeras possibilidades de dinamizar a economia dos municípios que a compõe, criando oportunidades e viabilizando o pleno desenvolvimento geoeconômico.

A produção agrícola da região geoeconômica 5 caracteriza-se como um dos setores mais produtivos economicamente, com ênfase para o cultivo da maçã. Juntamente com as regiões 4 e 6 , a região geoeconômica 5 individualizou-se, tendo como base culturas permanentes, situação que as distinguem dos demais recortes espaciais estabelecidos via lavoura empresarial. O maior produtor estadual de maçã é o município de Vacaria e, que no plano nacional, ocupa o segundo lugar. Além da maçã, se fazem presentes as lavouras de milho e, mais ao noroeste desta região, a soja, constituindo uma área de transição entre as regiões geoeconômicas 5 e 7 . Salienta-se também, a instalação de indústrias de beneficiamento em virtude da produção primária, como fábricas de sucos para beneficiamento da maçã, além de uma significativa frota de transporte rodoviário para escoamento da produção.

A configuração natural da paisagem, composta pelas maiores altitudes do Estado, aliada à estação de inverno e a probabilidade de ocorrência de neve, fenômeno raro no Brasil, viabiliza a atividade turística nesse recorte espacial. Trata-se, portanto, de uma atividade expressiva para a economia dessa região geoeconômica, com destaque para o conjunto de canyons (Itaimbezinho, no Parque Nacional dos Aparados da Serra), trilhas e cascatas, o que garante atrações durante 0 ano todo, não dependendo unicamente da estação mais fria.

No que se refere à região geoeconômica 6 seu recorte espacial caracterizou-se em função da produção da banana. A produção da banana é bastante significativa para os municípios que compõem esta região geoeconômica, constituindo-se na base da economia ao longo do ano e responsável pela sua inserção e manutenção no mercado consumidor local e regional. Além da banana, destacam-se as culturas do abacaxi e do palmito, como uma alternativa para diversificar a produção desta região geoeconômica, o que possibilita agregar renda ao pequeno produtor rural. Por se tratar de municípios litorâneos, durante o período de veraneio, há um incremento na economia local via atividade turística. O turismo constitui-se numa atividade geradora de renda para os habitantes desta região geoeconômica, dinamizando a economia e proporcionando novas perspectivas de desenvolvimento local/regional/nacional. No entanto, tal atividade é mais significativa no verão, ou seja, ao longo do ano a produção primária é a principal responsável pela sua organização socioeconômica.

A região geoeconômica 7 foi originada, tendo como base econômica as culturas da soja, do trigo e do milho, que constituem a sua matriz produtiva tradicional. Distintamente do que ocorreram nas demais regiões em que se fez necessário fazer subdivisões, a região geoeconômica 7 individualizou duas sub-regiões. A sub-região 7A caracterizada pela pecuária com a bovinocultura e a sub-região 7B pela avicultura. 
Salienta-se que a porção sudoeste desta região geoeconômica compõe a sub-região 7B, que faz divisa com a sub-região $1 \mathrm{~A}$ (região geoeconômica 1), e é composta pelos maiores municípios em termos de extensão territorial, bastante ligados à atividade pecuarista. Em contrapartida, a porção norte detém os menores municípios que compõem a sub-região 7B, em geral, formada através do processo de colonização, via Novas Colônias. Salienta-se que o caráter minifundiário é mantido até a atualidade, bem como a diversificação da produção primária, que, além da matriz produtiva tradicional, alia a sua produção a fruticultura e a avicultura.

Nesse contexto, recortou-se o Rio Grande do Sul em sete regiões geoeconômicas e suas respectivas sub-regiões, nas quais se desenvolvem as principais atividades produtivas do Estado, em constante dinâmica, tendo em vista as transformações impostas pelos mercados nacional e internacional e, principalmente, pelo capital.

Então, procurou-se classificar as regiões geoeconômicas do Rio Grande do Sul de acordo com a sua dinâmica, em função dos novos atores econômicos que se inserem neste espaço produtivo. Assim, adaptou-se a proposta de regionalização de Bacelar (1999), a qual individualiza três tipos de regiões: (a) as regiões dinâmicas ou competitivas; (b) as regiões em processo de reorganização econômica e (c) as regiões com potencial pouco utilizado. Desta forma, as regiões dinâmicas ou competitivas do território gaúcho são caracterizadas pelas regiões geoeconômicas 3 e 4. (Figura 3).

A região geoeconômica 3 caracteriza-se por ser uma região dinâmica e competitiva, pois apresenta na sua estrutura regional os três setores produtivos:

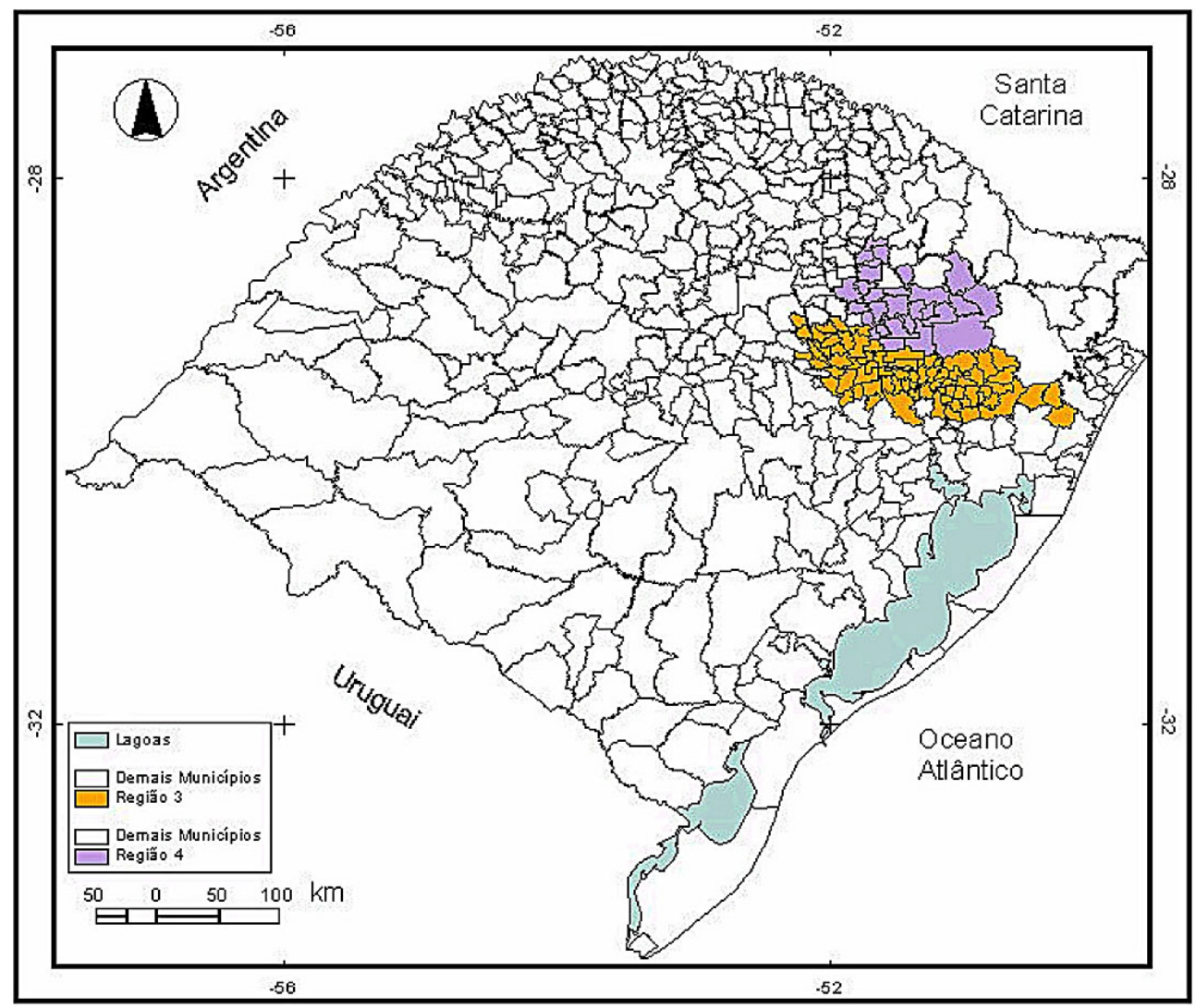

Figura 3. Regiões Geoeconômicas Dinâmicas e Competitivas do RS.

Fonte: Elaboração a partir do software ArcView 3.2a.

Org.: Equipe técnica - NERA/2005 
primário, secundário e terciário. A região geoeconômica 4 também individualizou um espaço dinâmico e competitivo, tendo na cadeia produtiva da fruticultura, representada pela uva, seu principal agente dinamizador, além de desenvolver o setor secundário, no qual situa-se o segundo pólo industrial em importância no estado gaúcho, e da atividade turística. Esta atividade econômica possibilita desenvolver esta região e estimula a oferta de empregos, caracterizando-se como uma das regiões mais dinâmicas do Rio Grande do Sul. (Figura 3).

Seguindo a classificação proposta por Bacelar (1999), as regiões geoeconômicas 1 com as suas respectivas sub-regiões $1 \mathrm{~A}, 1 \mathrm{~B}$ e $1 \mathrm{C}$, a região geoeconômica 2 e a região geoeconômica 7 e suas sub-regiões 7A e 7B foram agrupadas como regiões em processo de reestruturação econômica. (Figura 4). Desse modo, a região geoeconômica 1 , como um todo, enquadra-se como região em processo de reestruturação econômica, pois, recentemente, novas dinâmicas tem se inserido neste recorte espacial, via fruticultura e florestamento. Tal situação configura novas funções às velhas formas que compõem esta porção do espaço e demonstra as que, na atualidade, a paisagem é composta tanto pelas atividades produtivas mais tradicionais, como a pecuária e as lavouras de arroz, quanto pelas lavouras de soja, via nova expansão desta cultura e, mais recentemente, pela fruticultura e pelo florestamento. São justamente estas cadeias produtivas recentes que buscam o desenvolvimento desta região geoeconômica.

Entretanto, tendo em vista a dimensão desta

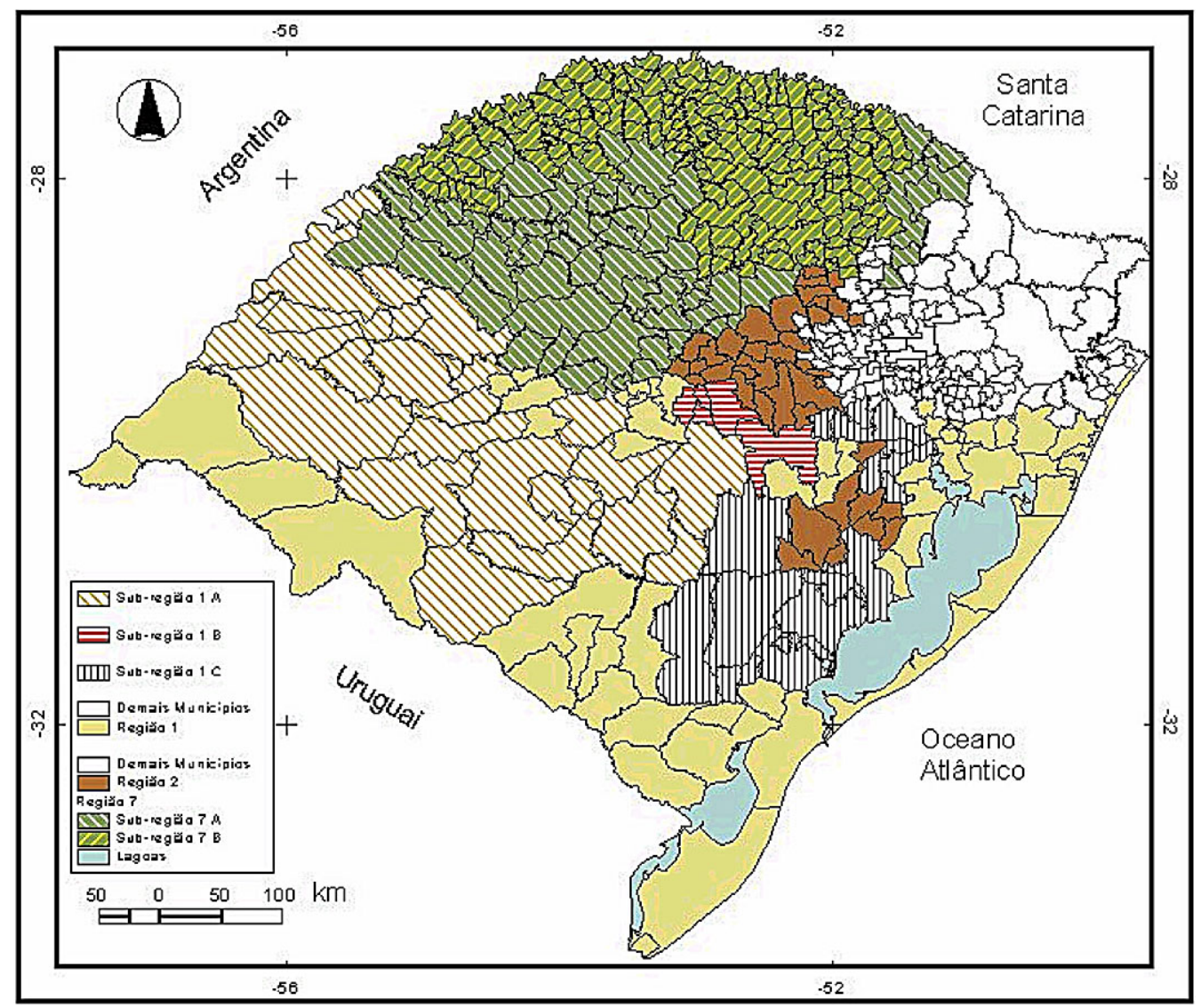

Figura 4. Regiões e Sub-regiões Geoeconômicas em Processo de Reestruturação Econômica no RS.

Fonte: Elaboração a partir do software ArcView 3.2a.

Org.: Equipe técnica - NERA/2005 
região geoeconômica e sua conseqüente divisão em sub-regiões geoeconômicas, fêz-se necessário ressaltar algumas porções deste espaço produtivo riograndense, que permanece como áreas sub-utilizadas. Tal fato é decorrente da sua utilização baseada na matriz produtiva tradicional, pecuária de corte e arroz, onde se convencionou denominá-las de áreas tradicionais. Desse modo, individualizaram-se algumas áreas nesta região geoeconômica com estas características, situando-se na porção oeste, centronorte e nos extremos leste e sul do Rio Grande do Sul.

É importante destacar também, que são porções do espaço regional com as maiores dificuldades para se inserirem no mercado produtivo. Apresentando áreas com baixos potenciais produtivos, decorrentes das condições limitantes dos aspectos físico-naturais; da baixa densidade demográfica; dos problemas estruturais de oferta de emprego; da deficiente infra-estrutura da malha viária; da baixa inserção e uso de tecnologias, além da baixa rentabilidade dos produtores rurais.

Portanto, faz-se necessário a inserção de novas atividades que visem a dinamizar estas porções do espaço da região geoeconômica 1 , ou mesmo, incrementar as já existentes. Para tanto, deve-se viabilizar a utilização de tecnologia de ponta para a agropecuária existente, na busca de se obter maior competitividade econômica, bem como a sua inserção no contexto regional como um todo, que passa na atualidade por um processo de reestruturação.

A região geoeconômica 2 insere-se como uma região em processo de reorganização espacial, uma vez que foi individualizada pela cultura do fumo, que tem apresentado, no decorrer do tempo, uma expansão significativa em área plantada e produção, sendo uma cultura que se utiliza de alto suporte tecnológico. (Figura 4).

Além disso, o fumo é uma das culturas com maior rentabilidade no mercado, com incentivo das multinacionais que organizam esta cadeia produtiva, via pacote tecnológico. Caracteriza-se, também, por ser uma área polarizadora de empregos, principalmente nas indústrias fumageiras, e também de serviços relativos a esta produção.

A região geoeconômica 7, subdividida em sub-regiões 7A e 7B, caracterizou-se como uma região em processo de reorganização espacial. Tal reestruturação espacial ocorre frente às novas dinâmicas econômicas viabilizadas para esta região através da expansão da cadeia produtiva das aves e do milho, da presença recente da cadeia produtiva da fruticultura e do revigoramento da cultura da soja, via transgênicos. Por ser a maior região em número de municípios, é explicável que a sua reestruturação seja bastante dinâmica, pois o capital e a tecnologia são assimilados de formas distintas pelos recortes espaciais, criando e recriando arranjos econômicos.

A terceira classificação reagrupou as regiões geoeconômicas 5 e 6 , e foram consideradas como regiões com potencial pouco utilizado. (Figura 5). A região geoeconômica 5 é caracterizada pela pecuária de corte e pela maçã e constitui-se em uma região com potencial pouco utilizado, em conseqüência das suas potencialidades físico-naturais sub-aproveitadas. Desta forma, tem-se as pequenas propriedades, com seu espaço produtivo bem utilizado, através do cultivo da maçã. Por outro lado, a pecuária desenvolvida em médias e grandes propriedades necessita se modernizar para que possa buscar mercados mais dinâmicos, necessitando da incorporação de novas tecnologias para dinamizar sua produção. (Figura 5).

A região geoeconômica 6, individualizada pela presença da banana, caracterizou uma região com potencial pouco utilizado. Tal fato é conseqüência da sub-utilização do seu espaço produtivo pela cultura da banana, além da presença do palmito e do abacaxi. Da mesma forma que a região geoeconômica 5 , o potencial turístico necessita ser melhor aproveitado, pois a porção litorânea tem presença significativa de turistas apenas nos períodos de veraneio.

É importante salientar que as paisagens apresentam singularidades que são expressas através 


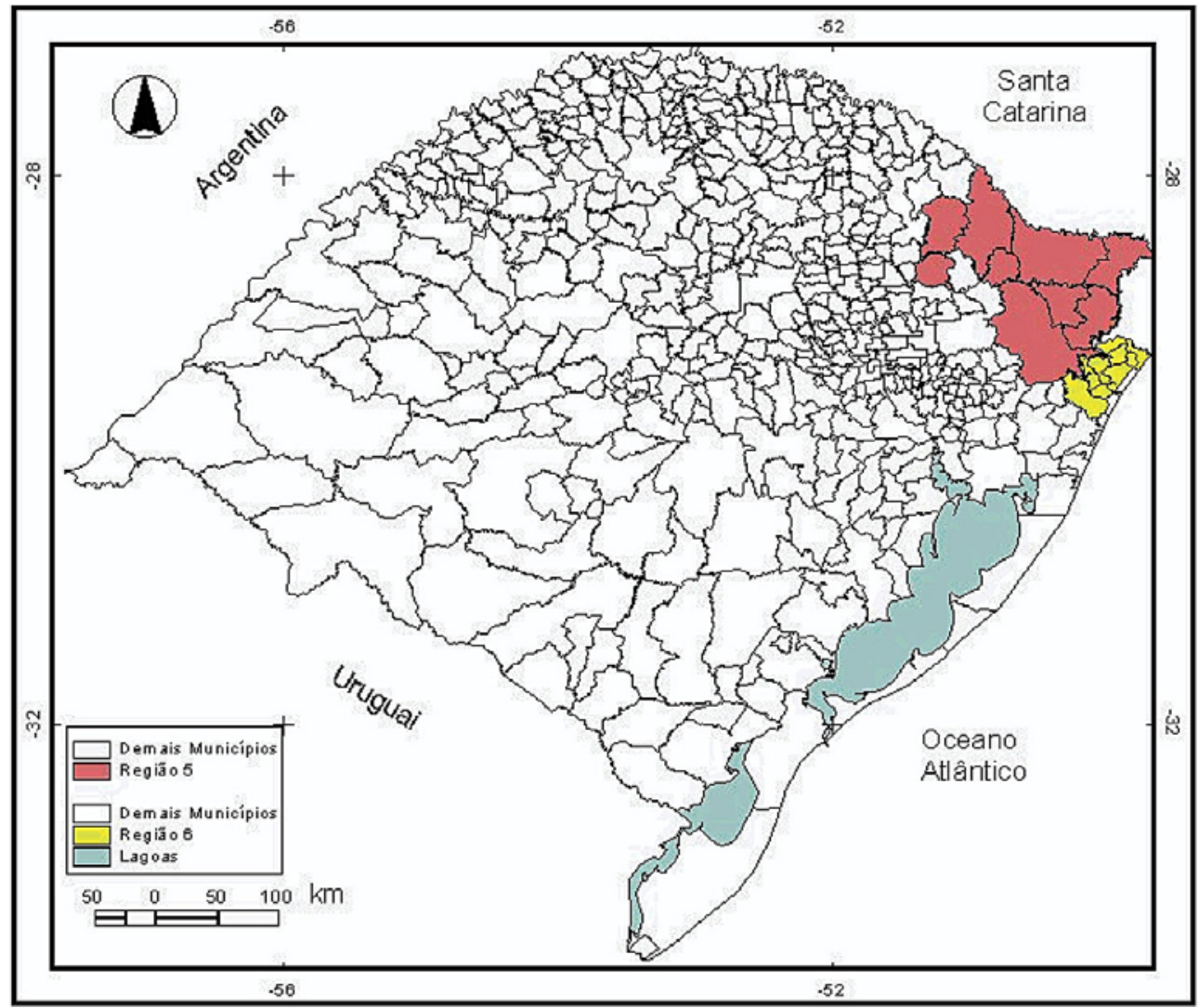

Figura 5. Regiões Geoeconômicas com Potencial Pouco Utilizado no RS.

Fonte: Elaboração a partir do software ArcView 3.2a.

Org.: Equipe técnica - NERA/2005

das belezas naturais aliadas ao processo colonizador. Tal configuração do espaço evidencia um potencial a ser melhor explorado, a exemplo das regiões geoeconômicas 3 e 4. Para tal, é necessário investir em um amplo planejamento que priorize a infraestrutura básica para o desenvolvimento do turismo.

Nesse contexto, diante da atual configuração do espaço Rio-Grandense, procurou-se classificar as sete regiões geoeconômicas estabelecidas em três categorias quanto as suas potencialidades para o desenvolvimento socioeconômico. Obviamente, a dinâmica do espaço, aliada as particularidades locais, não permite que este desenvolvimento seja homogêneo e compreenda todo seu contexto regional, o que Santos (1994) denomina de rugosidades do espaço.

No entanto, o homem, enquanto agente transformador do espaço, procura minimizar as diferenças sempre na busca de se obter o almejado desenvolvimento regional. Dessa forma, as particularidades culturais, que compõem cada grupo social, o torna singular em relação aos demais, bem como as suas manifestações em relação a sua base espacial. Nesse sentido, ao se analisar o espaço, deve-se considerar os agentes que o transformam, em todos os aspectos responsáveis por suas atitudes e que, conseqüentemente, se materializam no espaço.

Pode-se dizer, então, que o Rio Grande do Sul teve suas bases históricas atreladas aos distintos processos de ocupação, povoamento e colonização, os quais são os responsáveis diretos pela organização do seu espaço produtivo e, em conseqüência, pelo seu desenvolvimento econômico. Os níveis de desenvolvimento atuais nada mais são do que respostas 
ao processo de desenvolvimento pelo qual o Estado Gaúcho tem passado no decorrer do tempo e que resultaram nas sete regiões geoeconômicas individualizadas nesta proposta de regionalização.

\section{CONSIDERAÇÕES FINAIS}

A regionalização geoeconômica do Rio Grande do Sul individualizou sete regiões geoeconômicas e sub-regiões, nas quais se desenvolveram as principais atividades produtivas do Estado, baseadas, principalmente, na agropecuária. Considerando as transformações impostas pelo capital, como agente reorganizador dos padrões espaciais e responsável pela sua flexibilização frente às exigências impostas pelo processo de globalização, procurouse classificar as regiões geoeconômicas de acordo com a sua dinâmica e em função dos novos atores econômicos que se inserem neste espaço.

Dessa forma, no estado gaúcho, configuramse como regiões dinâmicas e competitivas as regiões geoeconômicas 3 e 4, situadas, respectivamente, na porção nordeste do Estado. A região geoeconômica 3 enquadra-se nesta classificação, pois apresenta a sua estrutura regional baseada nos três setores produtivos. O primário, individualizado pelas culturas do milho, da mandioca e, na pecuária, pelas aves, com crescimento significativo. O secundário, onde se concentra o maior pólo industrial do Rio Grande do Sul, representado por um amplo parque industrial, com finalidades distintas. O setor terciário, principalmente, na porção que abrange a Região Metropolitana de Porto Alegre, configura-se como pólo de serviços em geral. É importante destacar que esta região geoeconômica é caracterizada como a mais dinâmica e competitiva do Estado gaúcho, embora seu espaço produtivo esteja saturado, necessitando desconcentrar seu parque industrial e expandir sua malha rodoviária.

A região geoeconômica 4 individualizou um espaço dinâmico e competitivo, tendo na cadeia produtiva da fruticultura, representada pela uva, seu principal agente dinamizador. Paralelamente, apresenta o setor secundário desenvolvido, no qual se localiza o segundo pólo industrial em importância do Estado gaúcho, situado no entorno de Caxias do Sul, com ênfase para a indústria moveleira, calçadista e do vestuário. Outra forma de organização espacial desta região geoeconômica é representada pelo turismo.

No que se refere às regiões em processo de reestruturação econômica, tem-se a região geoeconômica 1 , com as sub-regiões $1 \mathrm{~A}, 1 \mathrm{~B}$ e $1 \mathrm{C}$, a região geoeconômica 2 e a região geoeconômica $7 \mathrm{com}$ as sub-regiões 7A e 7B. A região geoeconômica 1 enquadra-se nesta classificação, pois, recentemente, novas atividades têm se inserido, neste recorte espacial, via fruticultura e florestamento. Tal situação configura novas funções às velhas formas que compõem esta porção do espaço e demonstra que, na atualidade, a paisagem é composta tanto pelas atividades produtivas tradicionais, como a pecuária e as lavouras de arroz, como pela lavoura de soja, via nova expansão desta cultura e, recentemente, pela fruticultura e pelo florestamento.

A região geoeconômica 2 insere-se neste critério por ser uma região em processo de reorganização espacial, uma vez que foi individualizada pela cultura do fumo, que tem apresentado, no decorrer do tempo, uma expansão significativa em área plantada e produção, utilizando-se de alto suporte tecnológico. Caracteriza-se, também, por ser uma área polarizadora de empregos, principalmente nas indústrias fumageiras, de serviços relativos a esta produção.

A região geoeconômica 7, com suas subregiões 7A e 7B, também se insere neste critério de classificação. A reestruturação espacial ocorre frente às novas dinâmicas econômicas, viabilizadas através da expansão da cadeia produtiva das aves e do milho, da presença recente da cadeia produtiva da fruticultura e do revigoramento da cultura da soja, via transgênicos. Por ser a maior região em número de municípios, é explicável que a sua reestruturação seja diversificada, pois o capital e a tecnologia são assimilados, de formas distintas pelas unidades territoriais, criando e recriando arranjos econômicos 
singulares. Observa-se que as regiões geoeconômicas que se enquadram nesta classificação tem permitido a inserção de novos atores econômicos, os quais são responsáveis pela sua dinamização frente a matriz tradicional que a compõe, proporcionando novas alternativas para subsidiar o desenvolvimento local/ regional.

Como regiões com potencial pouco utilizado tem-se as regiões geoeconômicas 5 e 6 , localizadas, respectivamente, na porção nordeste e no leste do Rio Grande do Sul (litoral). A região geoeconômica 5 tem seu espaço produtivo caracterizado pela pecuária de corte e pela cultura da maçã e constituise em uma região com potencial pouco utilizado, em conseqüência das suas potencialidades físico-naturais sub-aproveitadas.

No que se refere à região geoeconômica 6 , individualizada pela cultura da banana e da presença do palmito e do abacaxi, sua inserção, nesta classificação é conseqüência da sua sub-utilização em decorrência das potencialidades naturais. Da mesma forma que a região geoeconômica 5 , o potencial turístico necessita ser dinamizado, pois a porção litorânea tem presença significativa de turistas apenas nos períodos de veraneio. É importante salientar que as paisagens apresentam singularidades que são expressas através das belezas naturais aliadas ao processo colonizador.

Tal configuração do espaço evidencia um potencial a ser explorado mais significativamente, a exemplo das regiões geoeconômicas 3 e 4, localizadas na Serra gaúcha. Para tanto, é necessário investir em um planejamento que priorize a infra-estrutura básica para o desenvolvimento do turismo e incentivar a intensificação da produção (através do fomento via políticas públicas), aliada a uma diversificação com produtos que proporcionem rentabilidade ao produtor, permitindo ao mesmo agregar valor a sua produção o ano todo.

Neste contexto, infere-se que a proposta de regionalização que recortou o Rio Grande do Sul em sete regiões geoeconômicas proporcionou uma visão geral do espaço produtivo gaúcho quanto as suas principais atividades econômicas, com ênfase para os produtos que caracterizam tais regiões e que constituem as matrizes produtivas tradicionais.

Assim, estruturadas as sete regiões geoeconômicas, fez-se uma releitura do espaço produtivo gaúcho, acreditando-se que a mesma possa subsidiar a tomada de decisões que promovam ações voltadas ao desenvolvimento local/regional do Rio Grande do Sul, minimizando, desta forma, as desigualdades regionais.

Embora o processo de regionalização pressuponha uma generalização, pois se observa o espaço como um "todo", no qual algumas particularidades não se salientam, procurou-se minimizar tal situação com o aprofundamento de algumas questões intrínsecas ao contexto regional. Para tanto, procurouse enfocar as particularidades regionais através das sub-regiões geoeconômicas, as quais foram individualizadas em virtude da coexistência de alguns produtos que visam a dinamizar tais espaços.

Assim, ao mesmo tempo em que se procurou demonstrar, de forma geral, como se estrutura o espaço produtivo gaúcho, também, salientou-se a atual inserção de algumas dinâmicas produtivas que tendem a promover o desenvolvimento local/regional (florestamento e fruticultura), pois apresentam possibilidades de reestruturação de um espaço tradicional da pecuária no Rio Grande do Sul, como a Campanha gaúcha.

Obviamente que um estudo mais detalhado segue-se a este, objetivando, justamente, aprofundar a visão geográfica das regiões geoeconômicas gaúchas, salientando as semelhanças e diversidades tecidas ao longo do processo evolutivo da sociedade gaúcha em sua relação com a natureza.

\section{REFERÊNCIAS}

BACELAR, T. Dinâmica regional brasileira nos anos noventa: rumo à desintegração competitiva? In: CASTRO, Iná. E.; MIRANDA, Mariana; EGLER, 
Cláudio A.G. (Org.). Redescobrindo o Brasil: 500 anos depois. Rio de Janeiro: Bertrand Brasil, 1999. p.73-91.

BEZZI, M. L. Região: Uma (Re)visão historiográfica - Da gênese aos novos paradigmas. Santa Maria: Ed. da UFSM, 2004.

EMPRESA BRASILEIRA DE PESQUISAAGROPECUÁRIA. Notícias. Disponível em: <http: // www. embrapa.br>. Acesso em: 10 nov. 2005.

FUNDAÇÃO DE ECONOMIA E ESTATÍSTICA. 25 anos de economia gaúcha. Porto Alegre: FEE, v. 3, 1978.

FUNDAÇÃO DE AMPARO AOS MUNICÍPIOS DO RIO GRANDE DO SUL. Municípios. Disponível em: < http:// www. famurs.com.br/ municípios>. Acesso em: 02-20 out. 2005.

GILBERT, A. The new regional geographic in English and French-speaking countries. Progress in humam geographic, London, v.12, n.2, 208-228, jun. 1988.

INSTITUTO BRASILEIRO DE GEOGRAFIA E ESTATÍSTICA. cidades @. Disponível em: < http: //www. ibge.gov.br/cidades@>.Acesso em: 02-out. 2005.

MOURA, L. G. V.; MIGUEL, L. A; ALMEIDA, J. A sustentabilidade na produção fumageira: as contradições entre o econômico, o social e o ambiental. (artigo científico). Disponível em: < http: www. Eco.unicamp.br/ projetos/rurbanos/zipados/ moura.pdf >. Acesso em: $10 \mathrm{dez}$. 2003.

PROFRUTA/RS apresenta balanço positivo ao completar um ano. A Platéia, Santana do Livramento, 03 set. 2004. Disponível em: < http: // www. aplateia.com.br >. Acesso em: 10 out. 2005.

RIO GRANDE DO SUL. Secretaria da Coordenação e Planejamento. Departamento de Estudos Econômicos e Sociais e de Planejamento Estratégico e Departamento de Coordenação e Acompanhamento de Projetos de Desenvolvimento Econômico e Tecnológico. Rumos 2015: estudos sobre o desenvolvimento e logística de transportes no Rio Grande do Sul: documento síntese. / SCP. DEPLANDCAPET. Porto Alegre: SCP, 2006. 473p.

SANTOS, M. Técnica, espaço, tempo: globalização e Meio Técnico-Científico Informacional. São Paulo: HUCITEC, 1994.

VIVIAN, J. L. Bananicultura em sistemas agroflorestais no litoral norte do Rio Grande do Sul. Agroecologia e Desenvolvimento Rural Sustentável, Porto Alegre, v. 3, n. 2, abr.jun., 2002, p. 1726.

Fruticultura muda a paisagem da Metade Sul. Zero Hora, Porto Alegre, 22 out. 2004. Disponível em: http: // www. zerohora.com.br>. Acesso em: 20 out. 2005. 